\title{
Iraqi Learners' Problems in Learning Speech Act of Request in EFL Classroom
}

\author{
Nadhim Obaid Hussein $^{1 *} \quad$ Intan Safinas Mohd Ariff Albakri ${ }^{2}$ \\ 1.Faculty of Languages and Communication, University Pendidikan Sultan Idris, Kula Lumpur, Malaysia \\ 2.Faculty of Languages and Communication, University Pendidikan Sultan Idris, Tg. Malim \\ Perak, Malaysia
}

\begin{abstract}
Presently, the control to master the English language has become prominent in academia, research and commercial attention. Therefore, many non-English speaking countries, including Arab countries such as Iraq, are striving to develop their education systems in teaching pragmatic aspects as speech act of request in classroom, and speech act of request is an essential aspect to boost English communication among Arab learners. Furthermore, in Arab countries as in Iraq, there is a lack of usage of speech act of request among students of English as a foreign language which affects the learning process of students. As such, teaching pragmatic aspect, particularly teaching speech act of requests, are emerging as the best way to create enthusiasm in learning new languages. Therefore, the paper was presented by a public syllabus lead that prioritizes the need for English learners to improve their ability to utilize speech act of request positively in social and cultural communications. Moreover, Many English learners fail to present pragmatic ability on how to understand speech act of request by relating utterances to their meanings, knowing the intention of language users, and how speech act of request is utilized in definite contexts. There is growing material of researches on usage of speech act of request for EFL schoolroom teaching. However, researchers have pointed to concentrate on the traditional approaches rather than how English learners require or understand how make speech act of request for developing the students' production of request in the EFL schoolroom. The usage of speech act of request and methods of teaching English to these Iraqi learners have been discussed in details of the current paper.
\end{abstract}

Keywords: Usage of Speech Act of Request, Iraqi Learners' Problems.

DOI: $10.7176 / \mathrm{JEP} / 10-4-07$

\section{Introduction}

The teaching of English language is continuously affected by social and cultural influences. Many Arab learners, attending the EFL classes, come from the background where English is unknown. Of course they are taught English in their primary and secondary schools, but they are taught English only as a formality. Most learners spend their time on memorizing of vocabularies and language rules in order to pass the examination without learning pragmatic aspects such as speech act of request. As a result, they spend their valuable years in school or university without learning anything of speech act which is regarded as a type of act of communication. Previous studies (Canale, 1983; Krasner, 1999; Kurdghelashvili, 2015) confirmed that understanding only vocabulary or grammar is insufficient to be a competent language learner in classroom. English learner considered as an excellent language learner may not be able to communicate with students of the target language. Therefore, English students need to have communicative competence which contains both competences such as language competence and pragmatic competence for obtaining communication among students in diverse environments. Language competence contains pronunciation, vocabulary, spelling, word formation, and sentence rules while pragmatic competence concerns students' use of language and picking the suitable utterance in the given situation (Leung, 2005).

Furthermore, pragmatic competence is regarded as one of the major components in the communicative language (Hymes, 1972). As well as, Bataineh and Hussein (2015) stated pragmatic doesn't focus on grammatical knowledge, but it focuses on the meaning of learners' language use in the acts of communication, Moreover, it focuses on helping learner to create meaning rather than improve perfectly grammatical structure. A study by Hussein and Elttayef (2018) indicated that EFL learners' pragmatic which is an aspect of communicative competence. Such pragmatic should be successfully and purposefully chosen in such a way that they should be more testable, interesting, motivating in FL classroom. Hence, pragmatic plays a vital role in obtaining different cultures of the foreign language. Through pragmatic competence, English learners can achieve diverse cultures of language. EFL learners display pragmatic competence when the written or spoken language produced is polite and culturally suitable. Also, pragmatic competence is defined as the students' use of language and utilizes appropriate rules and politeness dictated by the way it is understood by the student and express speech acts such as request strategies (Koike, 1989). In order to achieve the objectives of students' communication, and develop students' pragmatic ability in the EFL classroom. Therefore, students should recognize speech acts, namely request strategies, that students employ in their utterances and discover strategies employed by the learners to achieve their communication objectives in diverse countries. This may help foreign students become more pragmatically and culturally aware of their own utterances, and provide insight into language teachers in order to develop EFL 
students' pragmatic competence in EFL situations.

More significantly, it was found that EFL learners in a college in Iraq seem to sometimes lack pragmatic aspects such as speech act of request when trying to speak in English, which is their foreign language. As a result, Iraqi students seem less request polite when communicating in the English language, also they face difficulties when they produce speech acts specifically when performing face-threatening acts (FTA) such as speech act of requesting. As well as Cohen (1996) language learners can have all of the language rules and lexical items and still not be able to communicate their message because they lack the necessary pragmatic aspects to communicate their intent. Although some Iraqi learners seem pragmatically competent when speaking in the Arabic language, this competence is not necessarily reflected in their foreign language. Therefore, they need to learn pragmatic aspects such as speech act of request to permit them to make the speech act of request suitably, and they also become more pragmatically and culturally aware of their own utterances.

\section{Research on Speech Act of Request in EFL Learning and Teaching}

Numerous researches have shown the main role of speech act of request on increasing English learners' communication in the EFL classroom (Bachman, 1990; Schmidt 1993; Bardovi-Harlig \& Hartford, 1997). As well as Bardovi-Harlig \& Dörnyei, (1997) stated that syntactic development does not confirm an equivalent level of speech act development, and even excellent learners may not be able to understand or convey their intended objectives and contents (Eslami- Rasekh, 2005). For example, a language learner may pass an exam, but they are not able to convey the same language suitably in real-life situations because of the lack of speech act of request. Most of Iraqi EFL learner face problems when they want to communicate with individuals that is because they lack pragmatic aspects namely, speech act of request (Mohammed, 2012). Kasper (1989) revealed that excellent learners' communicative acts usually had pragmatic failures and proposed that there was a need for teaching speech act of request to include the application of pragmatic aspects, specifically, speech act of request (Bardovi-Harlig \& Hartford, 1997). Consequently, teaching of speech act of request has been identified as one of the important aspects that help language students become effectively competent in social and cultural communication.

Various studies had provided that the learners were aware that learning speech act of requests were a portion of their language learning and pragmatic aspects (Yang, 1999; Hong-Nam and Leavell, 2006; Tuncer, 2009; Li, 2010). Speech acts were the most prioritized actions that helped on enhancing learners' communicative language in the EFL classes (Hartford, 1997). Many researches explained the main role of speech act of request in emerging students' production of request in EFL contexts (Bardovi-Harlig \& Hartford, 1997; Bremner, 1998; Tuncer, 2009). Thus, this research highlights the learning of speech act of request on increasing learners' communication skills and its relation with the language production to better know Iraqi students learning locations.

Additionally, it was noted that practical speech act of request helped language students improve their communicative actions and pragmatic aspects in the EFL situations (Shridhar \& Shridhar, 1986, 1994; Sheorey, 1999). It was also noticed that speech act of request helped EFL students become more effective in their communicative environments mainly in-class discussions. The learners' social and cultural backgrounds influenced some of the speech act of requests they utilized. As well as Yang (1999) indicated quantitative proof to discover English students' learning speech act of request in the context of an indigenized form of English. The findings revealed that the vital role of teaching speech act of request relevant to cultural and educational backgrounds used in English language. Furthermore, the many studies focused on learning speech act of request in language learning have displayed that language learning strategies are essential to learners in developing their language communication, especially in EFL situations (Griffiths, 2003; Ersözlü, 2010; Li, 2010; Purdie \& Oliver; Hong-Nam \& Leavell, 2006; Yilmaz, 2010). Therefore, the researcher attempts to focus on the learning speech act of request for developing Iraqi students' communicative language in EFL classroom.

\section{Iraqi Students' Problems in Language Communication}

Our experience in teaching English as a foreign language in schools or universities, and other educational institutions in Iraq has led me to believe that English language majors/graduates in Iraq have problems in using English for communication, not only in academic expressions but also even in situational conversions of street. When engaged in authentic communicative situations, they often lack the necessary learning speech act of request they need to get their meaning across. As a result, they cannot keep the interaction going for an extended period of time. They don't exposure to real life situation for making requests. There is absent of communication with native speaker. There is absent teaching of speech act of request in the EFL classrooms. Therefor. There have been several problems made about the weakness in English of school graduates who join the universities as English language majors or as English language learners. Because of the seriousness of the problem. Basically, Iraqi students face many difficulties in communicative language. The great number of erroneous utterances that Iraqi students of English produce in oral performance and their recourse to communication, as presented in Rababah's research (2001), is an indication of how serious the problem is. It is also an indication that the goals of the English departments in the Arab world have not yet been achieved, and that this situation requires a solution. 
In the same way, Elttayef and Hussein (2017) stated that students are not taught English in a proper way in their schools for many reasons that is outside and inside of the school. Therefore, the students in Iraq, for instance, learn English in their native country, where the native language is Arabic. The only way to learn English in Iraq is through formal instruction, i.e. inside the classroom where the language teachers at school or university are native speakers of Arabic. There is little opportunity to learn English through natural communication in the target language and don't contact with native English speaker. This is only possible when learners encounter native speakers of English who come to the country as tourists, and this rarely happens (Rababah, 2002). Moreover, Suleiman (1983:129) discusses that the most noticeable difficulties which impede the progress of Arab learners at university level may be attributed to the "inadequate mastery of the four language communication skills; namely listening, speaking, reading and writing". As a result, there are many problems face Iraqi students such as there is a lack of teaching and learning of speech act of request, it's considered is a one of most important aspect of communication in EFL classrooms. Consequently, they lose interest in English language and consider it the most difficult subject. At this stage English teacher plays a vital role. If a teacher is dedicated, competent, and understands how to teach aspects of pragmatic such as speech act of request in EFL contexts, he rescues his students from their frustration. Also, give the students an opportunity to contribute the act of communication.

\section{Conclusion}

To conclude of the paper, Arab students in general, and Iraqi students in particular face many problems in both communication and lack of learning speech act of request: such as produce of requests in their communication. Also, the great amount of erroneous utterances that Iraqi learners of English produce in oral performance and their recourse to communication requests, as shown in the author's study (Authors, 2018) is an indication of how serious the problem is. It is also an indication that the objectives of the English departments in Iraq classroom, have not yet been attained, and that this circumstances requires a real solution. Basically, the researchers tend to put remedies and resolve problems of real communication in the 21th century schoolroom. Through learning of speech act of request, EFL Iraqi students can produce a suitable requests.

Continuously, the outcomes of the author's study (Authors, 2018) revealed that even weak students were good at transmitting understandable and positive messages. This is probably a finding of the new method to teach request strategies to resolve problems. Additionally, Further education college students and school students should, therefore, be aware of how to make requests and appreciate their value in act of communication. Additionally, Weak students will like the idea as it makes things easier for them and helps them to solve their communication problems.

\section{Reference}

Bachman, L. (1990). Fundamental consideration in language testing. New York: Oxford University Press.

Bardovi-Harlig, K., \& Hartford, B. (1997). Beyond methods: Components of second language teacher education. New York: McGraw-Hill.

Bardovi-Harlig, K., \& Dörnyei, Z. (1997). Pragmatic awareness and instructed L2 learning: An empirical investigation. Paper presented at the AAAL 1997 Conference, Orlando.

Bataineh, A. \& Hussein, N. (2015). The effect of using web-cam chat on the undergraduate EFL students' pragmatic competence. International Journal of education. ISSIN 1948-4576. VO.7.NO .2.

Bremner, S. (1998). Language learning strategies and language proficiency: Investigating the relationship in Hong Kong. Asian Pacific Journal of Language in Education, 1(2), 490-514.

Canale, M. (1983). From communicative competence to language pedagogy. In J. Richards \& R. Schmidt (Eds.), Language and Communication (pp. 2-27). London: Longman.

Cohen, A. D. (1996). Developing the ability to perform speech acts. Studies in Second Language Acquisition, 18 , 253-267.

Elttayef, A, and Hussein, N (2017). Arab Learners' Problems in Learning English Language: A Teacher Perspective. Journal of literature, Languages and linguistic .ISSI 2222-1679.

Ersözlü, Z. N. (2010). Determining of the student teachers ${ }^{\text {ee }}$ learning and studying strategies.

Eslami-Rasekh, Z. (2005). Raising the pragmatic awareness of language learners. ELT Journal, 59(3), 199-208.

Griffiths, C. (2003). Patterns of language learning strategy use. System, 31(3), 367-383.

Hong-Nam, K., \& Leavell, A. G. (2006). Language learning strategy use of ESL students in an intensive English learning context. System, 34(3), 399-415.

Hussein, $\mathrm{N}$ and Elttayef, A (2018). The effect of authentic materials on developing undergraduate EFL students' communicative competence. Journal of literature, Languages and linguistic .ISSI 2422-8535.

Hymes, D. (1972). On communicative competence. In J. B. Pride \& J. Holmes (Eds.),

Sociolinguistic (pp.269-285). Harmon sworth: Penguin.

Kasper, G. (1989). Variation in interlanguage speech act realization. In S. Gases, C. Madden,

Krasner, I. (1999). The role of culture in language teaching. Dialog on Language Instruction, 13(1-2), 79-88. 
Koike, D.A. (1989). Pragmatic competence and adult L2 acquisition: Speech acts in interlanguage. The Modern Language Journal, 73(3), 279-289.

Kurdghelashvili, T (2015) Speech Acts and Politeness Strategies in an EFL Classroom in Georgia. World Academy of Science, Engineering and Technology International Journal of Cognitive and Language Sciences .Vole: 9 , No: 1.

Leung, C (2005).Convivial communication: decontextualizing communicative competence. International Journal of Applied Linguistics, vo.15, no.2, 119-144.

Liu, A. (2010). On pragmatic "borrowing transfer" evidence from Chinese EFL learners' compliment response behavior. Chinese Journal of Applied Linguistics, 33(4), 26-44.

Mohammed, M. (2012) Teach ability of Pragmatic Competence: The Impact of Explicit Instruction on the Development of Iraqi Freshmen EFL Learners' Pragmatic Competence. Journal of Arab gulf, 34(2), 54-66.

Rabab'ah,G. (2002). Communication problems facing Arab learners of English. Journal of Language and Learning, 3(1), ISSN 1740-4983.

Schmidt, R. (1993). Consciousness, learning and interlanguage pragmatics. In G. Kasper

Sheorey, R. (1999). An examination of language learning strategy use in the setting of an indigenized variety of English. System, 27(2), 173-190.

Shridhar, K., \& Shridhar, S. (1986). Bridging the paradigm gap: Second language acquisition theory and indigenized varieties of English. World Englishes, 5, 3-14.

Suleiman, S. (1983). Teaching English to Arab students at the university level. In E. Dahiyat, and M. Ibrahim (eds.), Papers from the First Conference on the Problems of Teaching English Language and Literature at Arab Universities. Amman-Jordan: University of Jordan.

Tuncer, U. (2009). How do monolingual and bilingual language learners differ in use of learning strategies while learning a foreign language? Evidences from Mersin University. Procedia Social and Behavioral Sciences, $1(1), 852-856$.

Yang, N. D. (1999). The relationship between EFL learners' beliefs and learning strategy use. System, 27(4), 515535 .

Yilmaz, C. (2010). The relationship between language learning strategies, gender, proficiency and self-efficacy beliefs: A study of ELT learners in Turkey. Procedia Social and Behavioral Sciences, 2(2), 682-687. 